Available online at GSC Online Press Directory

GSC Advanced Research and Reviews e-ISSN: 2582-4597, CODEN (USA): GARRC2

Journal homepage: https://www.gsconlinepress.com/journals/gscarr

(RESEARCH ARTICLE)

\title{
Bone mineral density and nourishment
}

\author{
Ćatović Amra*, Bajgorić Ersan and Agić Almedin \\ Faculty of Medicine, University of Sarajevo Bosnia and Herzegovina.
}

Publication history: Received on 15 November 2020; revised on 25 November 2020; accepted on 30 November 2020

Article DOI: https://doi.org/10.30574/gscarr.2020.5.3.0115

\begin{abstract}
Some diet pattern is connected with higher risk of obesity and deficit of different nutrients. Both can contribute to complications of chronic disease like osteoporosis. The primary objective of this study was to analyze the correlation between bone mineral density and body mass, i.e. nutrients intake. The cross-sectional study included 25 patients who had regular osteodensitometrycal checkup. Patients anthropometrics' characteristics were collected by interview. Dietary pattern was estimated through food-frequency questionnaire and average meal was made. Nutritional analysis computer program (Nutrics Professional Nutrition Analysis Software) was used to analyze the average intake of nutrients from the food intake data. The average T score of hip was at level of osteopenia ( -1.7$)$, and BMI was 25.80 $\mathrm{kg} / \mathrm{m}^{2}$. By comparing the results using Pearson coefficient, we found positive linear trend and statistical significance at $p<0.05$. The average T score of lumbar spine was at level of osteoporosis $(-2,19)$, and average intake of calcium was $1519 \mathrm{mg}$. By comparing the results using Pearson coefficient, we found negative linear trend and statistical significance at $\mathrm{p}<0.05$. These data indicate that BMI and nutrients intake are connected with the risk for osteoporosis. There is the need for osteoporosis prevention strategies based on nutrition recommendations.
\end{abstract}

Keywords: Bone health; Nutrients; Osteoporosis; Prevention

\section{Introduction}

Osteoporosis has been identified as a major public health concern [1]. Characteristics of this common skeletal disease are low bone strength and increased risk of fracture. Fractures are associated with adverse outcomes such as acute and chronic pain, diminished quality of life, disability, increased mortality, and substantial healthcare expenses. Postmenopausal women and men aged 50 and older are at risk of this disease [2]. The different degrees of nutrition in patients are associated with risk of chronic disease [3]. The most abundant minerals in the body (phosphorus and calcium) are essential nutrients important for the mineralization of bones and teeth. Vitamin D is a fat soluble vitamin which promotes calcium absorption in the gut and is required for bone growth and bone remodeling. Vitamin $\mathrm{K}$ is a fat soluble vitamin that plays an important role in bone health (especially postmenopausal) [4]. The primary objective of this study was to analyze the connection between bone mineral density and body mass, i.e. nutrients intake.

\section{Patients and Methods}

The study was designed as a cross-sectional study. The diet nutrients intake of patients presented on the Clinic of Nuclear Medicine of the Clinical Center University of Sarajevo was analyzed. The sample included 25 patients who had regular osteodensitometrycal checkup, express by T and Z score of the hip and lumbar spine. Patients anthropometrics' characteristics were collected by interview.

\footnotetext{
* Corresponding author: Ćatović Amra

Faculty of Medicine, University of Sarajevo Bosnia and Herzegovina.

Copyright (C) 2020 Author(s) retain the copyright of this article. This article is published under the terms of the Creative Commons Attribution Liscense 4.0.
} 
The research instrument was food-frequency questionnaire (FFQ) that was conducted during March 2015 for three days, so average meal was made for female and for mail subjects. Table 1. presents diet log of subject.

Table 1 Diet Log of Examiners.

\begin{tabular}{|l|l|l|l|}
\hline Meal & Day 1 & Day 2 & Day 3 \\
\hline Breakfast & $\begin{array}{l}\text { comflour, onions, half liter of } \\
\text { milk }\end{array}$ & cheese, ginger, 2 slices of bread & Sardines, 2 slices of bread \\
\hline Snack & 1 glass of milk & tea & jam fruit, 1 slice of bread \\
\hline Lunch & bread & $\begin{array}{l}\text { beans with beef, garden salad, } 2 \\
\text { slices of bread }\end{array}$ & $\begin{array}{l}\text { chicken soup, beef, slices of } \\
\text { bread }\end{array}$ \\
\hline Snack & 1 banana & 2 oranges & 2 apples,1 kiwi \\
\hline Dinner & 1 glass of yogurt & popcorn & 1 glass of compote \\
\hline
\end{tabular}

In this study nutritional analysis computer program (Nutrics Professional Nutrition Analysis Software) was used to analyze the average intake of nutrients from the food intake data.

Statistical analyses were performed using the Statistical Package for Social Sciences software (IBM, version 23.0). Continuous data were presented as mean and standard deviation (SD). In the bivariate analysis, the association (using Pearson's chi-squared test) of parameters of bone mineral density were estimated according to the nourishment status.

\section{Results}

Characteristics of the subjects are presented in Table 2. A total of 25 patients ( 2 males and 23 females), with a mean age \pm standard deviation, of $60.48 \pm 10.55$ years, participated in this study. The mean weight was $71.20 \pm 13.06$ and mean height was $165.96 \pm 8.65$. Mean BMI was $25.80 \pm 3.79$.

Table 2 Characteristics of the participants (means \pm SD).

\begin{tabular}{|l|l|l|l|}
\hline Variable & Total & Males & Females \\
\hline Number of Examiners & $\mathrm{N}=25$ & $\mathrm{~N}=2$ & $\mathrm{~N}=23$ \\
\hline Age (years) & $60.48 \pm 10.55$ & $56.00 \pm 14.14$ & $60.87 \pm 10.51$ \\
\hline Weight $(\mathrm{kg})$ & $71.20 \pm 13.06$ & $80.00 \pm 28.28$ & $70.44 \pm 11.92$ \\
\hline Height $(\mathrm{cm})$ & $165.96 \pm 8.65$ & $174.00 \pm 25.46$ & $165.7 \pm 6.80$ \\
\hline BMI & $25.80 \pm 3.79$ & $25.89 \pm 1.75$ & $25.79 \pm 3.94$ \\
\hline
\end{tabular}

Nutrients intake is presented in Table 3. Average phosphorus intake was $3660 \mathrm{mg}$, average calcium intake was 2024 $\mathrm{mg}$, average vitamin D intake was $6.5 \mu \mathrm{g}$, and average vitamin $\mathrm{K}$ intake was $86.9 \mu \mathrm{g}$.

Table 3 Single nutrient average intake

\begin{tabular}{|l|l|}
\hline Nutrients & Total \\
\hline Phosphorus $(\mathrm{mg})$ & 2219 \\
\hline Calcium $(\mathrm{mg})$ & 1519 \\
\hline Vitamin $\mathrm{D}(\mu \mathrm{g})$ & 5.3 \\
\hline Vitamin K $(\mu \mathrm{g})$ & 78.5 \\
\hline
\end{tabular}


Average hip T score was -1.55 SD (0.10 to -2.7), average hip Z score was -1.23 SD (1.70 to -6.00), average lumbar spine T score of -2.19 SD ( -1.0 to -3.30$)$ and average lumbar spine Z score of -1.38 SD (0.7 to -5.80). These results are shown by Figure 1.

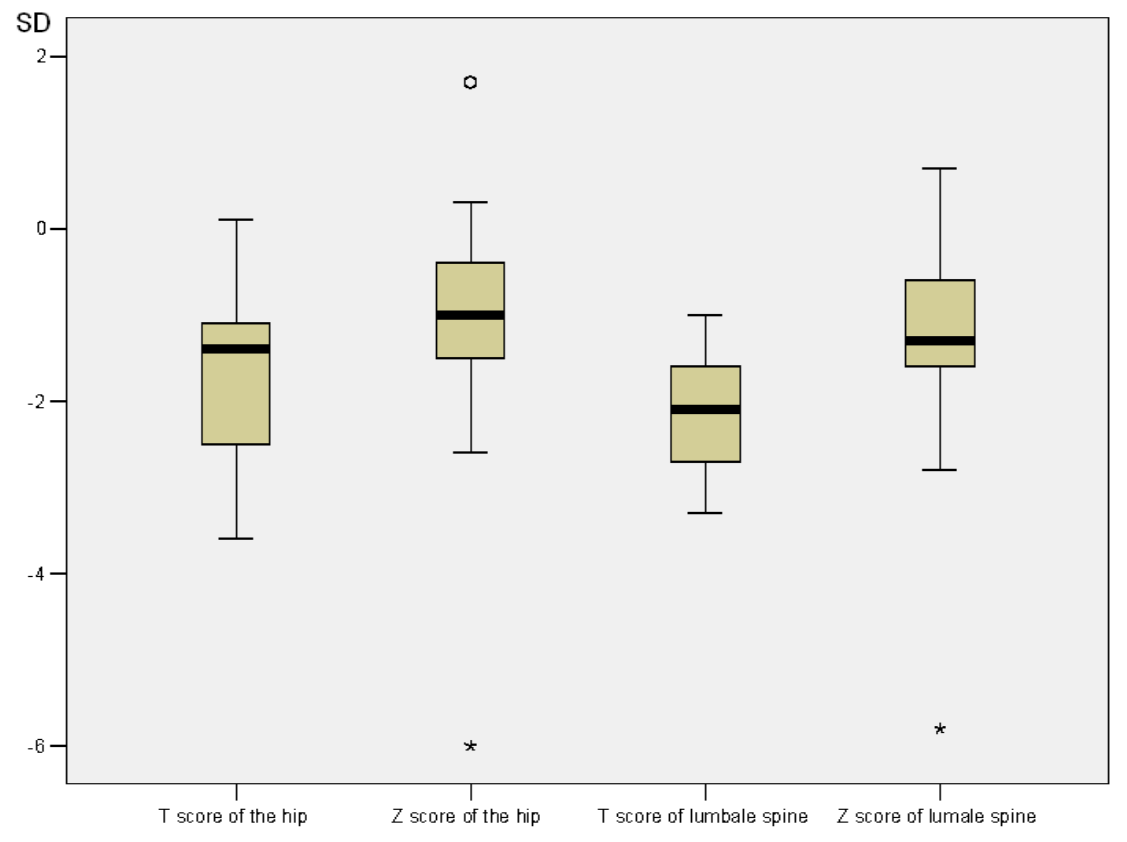

Figure $1 \mathrm{~T}$ and $\mathrm{Z}$ scores of the hip and lumbar spine

The average T score of hip was at level of osteopenia (-1.7), and BMI was $25,80 \mathrm{~kg} / \mathrm{m}^{2}$. By comparing the results using Pearson coefficient, we found positive linear trend and statistical significance at $p<0.05$. The average T score of lumbar spine was at level of osteoporosis (-2.19), and average intake of calcium was $1519 \mathrm{mg}$. By comparing the results using Pearson coefficient, we found negative linear trend and statistical significance at $\mathrm{p}<0.05$ (Table 4).

Table 4 Pearson's correlation coefficients between nourishment and parameters of bone mineral density $\left({ }^{*} \mathrm{p}<0,05\right)$

\begin{tabular}{|l|l|l|l|l|}
\hline \multirow{2}{*}{ Nourishment } & \multicolumn{4}{|l|}{ Parameters of bone mineral density } \\
\cline { 2 - 5 } & $\begin{array}{l}\text { T score of the hip } \\
(-1,75 \pm 0,903)\end{array}$ & $\begin{array}{l}\text { Z score of the hip } \\
(-1,07 \pm 1,46)\end{array}$ & $\begin{array}{l}\text { T score of } \\
\text { lumbar spine } \\
(-2,19 \pm 0,64)\end{array}$ & $\begin{array}{l}\text { Z score of } \\
\text { lumbar spine } \\
(-1,38 \pm 1,36)\end{array}$ \\
\hline $\begin{array}{l}\text { BMI } \\
(25,80 \pm 3,80)\end{array}$ & $0,460^{*}$ & 0,328 & 0,087 & 0,126 \\
\hline Phosphorus $(2219 \mathrm{mg})$ & 0,193 & 0,192 & $-0,303$ & $-0,192$ \\
\hline Calcium $(1519 \mathrm{mg})$ & 0,365 & 0,364 & $-0,495^{*}$ & $-0,364$ \\
\hline Vitamin $D(5.3 \mu \mathrm{g})$ & $-0,078$ & $-0,078$ &,- 102 & 0,078 \\
\hline Vitamin $\mathrm{K}(78.5 \mu \mathrm{g})$ & 0,287 & 0,286 & $-0,421$ & $-0,286$ \\
\hline
\end{tabular}

\section{Discussion}

The most common metabolic bone disease is osteoporosis [5]. Correlation between T scores and BMI indicate that a low body mass index can be a useful clinical tool for an early intervention to prevent osteoporosis and its complication [6].

Diet and lifestyle approach can prevent loss of bone mineral density and the progression to osteoporosis. A large and cooperative bone-making and maintenance team composed of nutrients and other compounds, including vitamins D and $\mathrm{K}$, and the minerals calcium and phosphorus. 
Calcium is crucial for preventing any bone-related diseases. Not all calcium consumed is absorbed and calcium recommendations (Recommended Dietary Allowances - RDAs) have been set high enough to accommodate a 30 percent absorption rate. The recommendation for adolescents to the age of 18 years is $1300 \mathrm{mg}$ daily, people between ages 19 and 50 should consume about $1,000 \mathrm{mg}$ of calcium a day; for women older than 50 and all adults older than 70 , recommendations are raised again to 1200 milligrams a day [7]. Milk and milk products are good sources of calcium. Suggested daily milk amounts for young children ( 2 to 8 year) are 2 cups, and for older children, teenagers, and all adults are 3 cups. Good sources are calcium-set tofu, bok choy, kale, calcium-fortified orange juice, and broccoli. Some dark green, leafy vegetables - notably spinach and Swiss chard-appear to be calcium-rich but actually provide little calcium because they contain binders that limit absorption [4].

Vitamin D's special role in bone health is to assist in the absorption of calcium and phosphorus. In vitamin D deficiency, production of calbindin, a protein that binds calcium in the intestinal cells, slows and calcium passes through the GI tract unabsorbed. Vitamin D can be obtained from sun exposure, foods, and supplements. The vitamin D RDAs are based on the assumption that people receive minimal sun exposure. The recommendation for adults between ages 19 and 70 is $15 \mu \mathrm{g} /$ day or $600 \mathrm{IU} /$ day; and for adults older than 70 is $20 \mu \mathrm{g} /$ day or $800 \mathrm{IU} /$ day [7]. Few foods naturally contain vitamin D. The best sources are the flesh of fatty fish (such as trout, salmon, tuna, and mackerel) and fish liver oils are among. Beef liver and egg yolks have small amounts of vitamin D. Cheese naturally contains small amounts of vitamin D. Mushrooms provide variable amounts of vitamin D depending on UV light exposing [8]. Milk, many ready-to-eat cereals, and some brands of yogurt and orange juice are fortified with vitamin D. Fortified foods provide most of the vitamin D [4].

Vitamin $\mathrm{K}$ participates in the metabolism of bone proteins, most notably osteocalcin, which bind to the minerals that form bones. Vitamin K is made in the GI tract by the billions of bacteria that normally reside there. Once synthesized, vitamin $\mathrm{K}$ is absorbed and stored in the liver. This source provides about half of a person's needs. Because of insufficient evidence to establish RDA, intake at the level of adequate intake (AT) is assumed to ensure nutritional adequacy. AI for men is $120 \mu \mathrm{g} /$ day and for women is $90 \mu \mathrm{g} /$ day [9]. Vitamin K-rich foods are green vegetables and vegetable oils can easily supply the rest [4].

Phosphorus is the second most abundant mineral in the body. About 85 percent of it is found combined with calcium in the hydroxyapatite crystals of bones and teeth. Over the years, researchers have emphasized the importance of an ideal calcium-to-phosphorus ratio to support calcium metabolism, but there is little or no evidence to support this concept [4]. The phosphorus RDA for adults is $700 \mathrm{mg} /$ day [10]. Significant sources are foods derived from animals (meat, fish, poultry, eggs, milk). Because phosphorus is commonly found in almost all foods, dietary deficiencies are unlikely.

Lifestyle choices can improve bone health. These include: increase physical activity; reduce sodium intake; increase consumption of fruits and vegetables; maintain a healthy body weight; avoid smoking; limit alcohol intake [3]. Bone forms and remodels in response to physical stress. For bone health weight-bearing physical activity and exercise that improves balance should be encouraged [11].

\section{Conclusion}

Data from our study indicate that BMI and nutrients intake are connected with the risk for osteoporosis. There is the need for osteoporosis prevention strategies based on nutrition recommendations. The findings of this study are limited by the use of a small sample from just one clinic which may not be a representative of all patients with osteoporosis in $\mathrm{B} \& \mathrm{H}$. However, baseline information about the relationship between bone mineral density and eating habits was certainly obtained from the present study.

\section{Compliance with ethical standards}

\section{Acknowledgments}

The authors would like to thank the participants who involved in this study.

\section{Disclosure of conflict of interest}

The authors declare that they have no competing interests.

\section{Statement of informed consent}


Informed consent was obtained from all individual participants included in this study.

\section{References}

[1] US Department of Health and Human Services. Bone Health and Osteoporosis: A Report of the Surgeon General. Rockville, MD, US Department of Health and Human Services, Office of the Surgeon General. 2004.

[2] National Osteoporosis Foundation. Clinician's Guide to Prevention and Treatment of Osteoporosis. Washington, DC: National Osteoporosis Foundation. 2014.

[3] WHO: Diet, nutrition and the prevention of chronic diseases. Technical Report, Series No. 916, WHO Geneva. 2003.

[4] Whitney EN, Rolfes SR. Understanding Nutrition, 15th edition, Wadsworth Cengage. 2017.

[5] Porter JL, Varacallo M. Osteoporosis. StatPearis Publishing. jan 2020.

[6] Zvekić Svorcan J, Filipov P, Stanimirov B, Filipović K, Subin Teodosijević S. Correlation between bone mineral density and body mass index as risk factor for the development of osteoporosis. Timočki medicinski glasnik. 2011; 36(4): 197-200.

[7] Committee to Review Dietary Reference Intakes for Vitamin D and Calcium, Food and Nutrition Board, Institute of Medicine. Dietary Reference Intakes for Calcium and Vitamin D. Washington, DC: National Academy Press. 2010.

[8] Roseland JM, Phillips KM, Patterson KY, Pehrsson PR, Taylor CL. Vitamin D in foods: An evolution of knowledge. Pages 41-78 in Feldman D, Pike JW, Bouillon R, Giovannucci E, Goltzman D, Hewison M, eds. Vitamin D, Volume 2: Health, Disease and Therapeutics, Fourth Edition. Elsevier. 2018.

[9] Institute of Medicine. Dietary reference intakes for vitamin A, vitamin K, arsenic, boron, chromium, copper, iodine, iron, manganese, molybdenum, nickel, silicon, vanadium, and zinc. Washington, DC: National Academy Press. 2001.

[10] Institute of Medicine, Food and Nutrition Board. Dietary Reference Intakes for Calcium, Phosphorus, Magnesium, Vitamin D, and Fluoride. Washington, DC: National Academies Press. 1997.

[11] Camacho PM, Petak SM, Binkley N, Diab DL, Eldeiry LS, Farooki A, et al. American Association of Clinical Endocrinologists/American College of Endocrinology Clinical Practice Guidelines for the Diagnosis and Treatment of Postmenopausal Osteoporosis-2020 update. Endocr Pract. 2020 May. 26 (Suppl 1):1-46. 